\title{
PENGARUH MODEL PEMBELAJARAN INQUIRY TRAINING TERHADAP HASIL BELAJAR SISWA
}

\author{
David Manurung ${ }^{1)}$ dan Makmur Sirait ${ }^{2)}$ \\ 1) Alumni Jurusan Fisika FMIPA Universitas Negeri Medan; \\ ${ }^{2)}$ Jurusan Fisika FMIPA Universitas Negeri Medan \\ e-mail: davidpatarmanurung@gmail.com
}

\begin{abstract}
Abstrak Penelitian ini bertujuan untuk mengetahui pengaruh model pembelajaran inquiry training terhadap hasil belajar siswa pada materi listrik dinamis. Jenis penelitian ini adalah quasi experiment dengan populasi seluruh siswa kelas X SMA Negeri 11 Medan yang berjumlah 8 kelas. Sampel penelitian ini terdiri dari 2 kelas yang ditentukan dengan teknik cluster random sampling, yaitu kelas X-8 sebanyak 40 orang sebagai kelas eksperimen dengan menggunakan model pembelajaran inquiry training dan kelas X-5 sebanyak 39 orang sebagai kelas kontrol dengan menggunakan pembelajaran konvensional. Setelah dilakukan perlakuan pada masing-masing kelas diperoleh rata-rata nilai postes pada kelas eksperimen sebesar 75,60 dan rata-rata postes kelas kontrol sebesar 62,18. Dari hasil pengamatan observer diperoleh rata-rata peningkatan aktivitas n-gain siswa cukup baik dari pertemuan I ke pertemuan II sebesar 0,58 dengan kategori sedang dan dari pertemuan II ke pertemuan III sebesar 0,86 dengan kategori tinggi. Dari hasil uji hipotesis diperoleh ada pengaruh yang signifikan model pembelajaran inquiry training terhadap hasil belajar siswa.
\end{abstract}

Kata Kunci : model pembelajaran inquiry training, pembelajaran konvensional, aktivitas, hasil belajar.

Abstract : This study aims to determine the effect of inquiry learning model training on student learning outcomes in a dynamic electrical material. This research is a quasi experiment with the entire population of class X SMA Negeri 11 Medan, amounting to 8 classes. The research sample consisted of two classes are determined by random cluster sampling technique, namely X-8namely 40people as the experimental class using inquiry learning model training and class X-5namely 39 people as the control class using conventional learning. After the treatment in each class earned an average post-test score in the experimental class at 75.60 and the average posttest control class is 62.18. From the observation observer obtained an average increase in the activity of n-gain students quite well from the first meeting to meeting II 0,58 with category II and from meeting to meeting with category III amounted to 0.86 higher. From the results of hypothesis test obtained no significant effect of inquiry learning model training on student learning outcomes.

Keywords: inquiry training, conventional learning, activity, learning outcomes.

\section{PENDAHULUAN}

Kemajuan suatu bangsa sangat ditentukan oleh kualitas sumber daya manusia dimana kualitas sumber daya manusia tersebut bergantung pada kualitas pendidikan. Pendidikan memegang peranan penting dalam pengembangan semua potensi, kecakapan, serta karakteristik sumber daya manusia ke arah positif baik bagi dirinya maupun bagi lingkungannya.
Penyelenggaraan pendidikan yang bermutu akan menghasilkan sumber daya manusia yang bermutu dan mempunyai daya saing. Pembangunan nasional di bidang pengembangan sumber daya manusia Indonesia yang berkualitas melalui pendidikan merupakan upaya yang sungguhsungguh dan terus-menerus dilakukan untuk mewujudkan manusia indonesia 
seutuhnya. Sumber daya yang berkualitas akan menentukan mutu kehidupan pribadi, masyarakat dan bangsa dalam rangka mengantisipasi, mengatasi persoalan-persoalan, dan tantangan-tantangan yang terjadi dalam masyarakat pada kini dan masa depan.

Pendidikan adalah suatu usaha sadar untuk menyiapkan peserta didik melalui kegiatan bimbingan pengajaran atau latihan untuk peranannya pada masa-masa yang akan datang. Dunia pendidikan memerlukan adanya program peningkatan pendidikan yaitu dengan mengatur peningkatan pendidikan dalam suatu perundangan. Setiap elemen yang terlibat dalam peningkatan pendidikan, baik pemerintah, masyarakat termasuk orangtua, dan siswa serta pihak yang terlibat langsung dalam dunia pendidikan yaitu sekolah harus dapat menunjang berhasilnya sebuah pendidikan. Keberhasilan pendidikan tesebut dapat dilihat dalam suatu sistem penilaian pendidikan. Penilaian hasil belajar oleh pendidik bertujuan untuk memantau proses dan kemajuan belajar peserta didik serta untuk meningkatkan efektivitas kegiatan pembelajaran. Tujuan tersebut dapat tercapai, jika dalam proses pembelajarannya menuntut agar siswa berperan aktif dalam pembelajaran terutama melalui kegiatan penemuan, sedangkan guru yang semula bertindak sebagai sumber belajar beralih fungsi menjadi fasilitator kegiatan pembelajaran yang berperan mengarahkan atau membimbing siswa untuk memecahkan masalah-masalah yang dihadapi dalam belajar atau menemukan sendiri konsep-konsep yang sedang dipelajari. Kenyataannya yang ada tidak semua tujuan pembelajaran tersebut berjalan sesuai pemahaman dan target yang sudah dibuat, dan berbagai masalah selalu kita temukan pada perwujudan tujuan pembelajaran tersebut.

Masalah utama dalam pembelajaran pada pendidikan formal atau sekolah dewasa ini adalah masih rendahnya daya serap peserta didik. Hal ini tampak dari rata-rata hasil belajar peserta didik yang senantiasa masih memprihatinkan. Prestasi ini tentunya merupakan hasil kondisi pembelajaran yang masih besifat konvensional atau selalu berpusat pada guru dan tidak menyentuh ranah dimensi pesera didik itu sendiri yaitu bagaimana sebenarnya belajar itu (belajar untuk belajar). Artinya, proses pembelajaran hingga dewasa ini masih memberikan dominasi guru dan tidak memberikan akses bagi anak didik untuk berkembang secara mandiri melalui penemuan dalam proses berpikirnya (Trianto, 2011:5).

Hal ini terbukti berdasarkan pengalaman peneliti saat melakukan Praktek PPLT di SMP N 1 Balige, banyak siswa yang mengatakan bahwa pelajaran fisika itu merupakan pelajaran yang sulit untuk dipahami dan pelajaran yang membosankan. Mereka juga cenderung menganggap pelajaran fisika selalu identik dengan rumus yang banyak dan susah untuk diingat. Guru lebih sering menggunakan pola mengajar dengan menyajikan materi dan penyelesaian soal-soal dengan rumus. Siswa hanya dapat menghitung tetapi tidak dapat mengerti konsep fisika sebenarnya. Permasalahan lain yang dijumpai di SMP Negeri 1 Balige adalah kurangnya keterampilan siswa di dalam penggunaan alat-alat laboratorium.

Kenyataan tersebut juga dapat dibuktikan berdasarkan observasi yang telah peneliti lakukan di SMA Negeri 
11 Medan yang menunjukkan bahwa minat dan motivasi belajar siswa khususnya pada mata pelajaran fisika masih tergolong rendah. Dari data hasil observasi yang telah peneliti lakukan tentang pendapat siswa terhadap mata pelajaran fisika menerangkan bahwa $56,4 \%$ dari 39 orang siswa mengatakan bahwa pelajaran fisika itu biasa saja dan disamping itu 33,3\% dari 39 orang siswa mengatakan bahwa pelajaran fisika itu sulit dan kurang menarik.

$$
\text { Ketidaktertarikan }
$$

siswa

terhadap pelajaran fisika disebabkan oleh banyak faktor yaitu diantaranya kurang beragamnya model pembelajaran dan media pembelajaran yang digunakan guru saat kegiatan belajar mengajar berlangsung. Hal ini dibuktikan dari hasil data observasi di SMA Negeri 11 Medan yang menunjukkan $46,1 \%$ dari 39 orang siswa mengatakan bahwa kegiatan belajar mengajar fisika selama ini di sekolah hanya dengan mencatat dan mengerjakan soal. Kegiatan belajar mengajar seperti ini maka siswa akan cepat bosan dan jenuh terhadap mata pelajaran fisika. Faktor lain yang menyebabkan siswa kurang suka belajar fisika adalah karena kurangnya pembelajaran menggunakan metode praktikum atau eksperimen saat belajar. Kurangnya minat belajar siswa terhadap mata pelajaran fisika berakibat pada nilai siswa yang masih relatif rendah.

Salah satu alternatif yang diduga dapat menciptakan kegiatan belajar mengajar yang menyenangkan, serta yang bersifat dapat melatih siswa melakukan penelitian untuk menemukan konsep adalah menerapkan model pembelajaran inquiry training. Model ini bertujuan untuk melatih kemampuan siswa dalam meneliti, menjelaskan fenomena dan memecahkan masalah secara ilmiah. Model inquiry training juga sangat penting untuk mengembangkan nilai dan sikap dalam berpikir ilmiah (Toenas, 2012).

Model pembelajaran inquiry training dipilih karena model pembelajaran inquiry training merupakan model yang sesuai dengan perkembangan psikologi belajar modern yang menganggap belajar adalah proses perubahan tingkah laku berkat adanya pengalaman (Sanjaya, 2010)

Model inquiry training adalah model pembelajaran dimana pengajar melibatkan kemampuan berpikir kritis pembelajar untuk menganalisis dan memecahkan persoalan secara sistematik. Latihan inquiry bertolak dari kepercayaan bahwa agar seseorang menjadi mandiri, dituntut metode yang dapat memberi kemudahan pada pembelajar untuk melibatkan diri dalam penelitian ilmiah. Model pembelajaran ini menggunakan pendekatan induktif dalam menemukan pengetahuan dan berpusat pada keaktifan pembelajar, bukan pembelajaran yang berpusat pada pengajar. Isi dan proses penyelidikan dalam model pembelajaran ini diajarkan bersama-sama dalam waktu yang bersamaan. Pembelajaran melalui proses penyelidikan akhirnya sampai kepada isi pengetahuan itu sendiri. Tujuan umum dari model pembelajaran inquiry training adalah membantu peserta didik mengembangkan keterampilan intelektual dan keterampilan-keterampilan lainnya seperti mengajukan pertanyaan dan menemukan jawaban yang berawal dari keingintahuan mereka. 
Model pembelajaran inquiry training dikemukakan oleh Suchman dan pada dasarnya model ini mengikuti teori Suchman yaitu sebagai berikut: 1 . Secara alami pembelajar akan mencari sesuatu setelah dihadapkan dengan masalah. 2. Mereka akan segera sadar tentang belajar mengenai strategi berpikir yang dimilikinya. 3. Penelitian yang bersifat kerjasama akan memperkaya proses berpikir dan membantu pembelajar untuk belajar tentang sifat tentatif dari pengetahuan, sifat selalu berkembang dari pengetahuan dan menghargai berbagai alternative penjelasan mengenai suatu hal (Rusman,2010).

Joyce dan Weil, (2009) mengemukakan pembelajaran inquiry training memiliki lima langkah pokok yaitu: (1) Menghadapkan pada masalah : menjelaskan prosedur penelitian, menjelaskan perbedaanperbedaan,

Pengumpulan data (verifikasi) : memverifikasi hakikat objek dan kondisinya, memverifikasi peristiwa dari keadaan permasalahan, (3) Pengumpulan data (eksperimentasi) : memisahkan variabel yang relevan, menhipotesiskan (serta menguji) hubungan kausal, (4) Mengolah, memformulasikan suatu penjelasan : memformulasikan aturan dan penjelasan, (5) Analisis proses penelitian : menganalisis strategi penelitian dan mengembangkan yang paling efektif.

Model pembelajaran inquiry training memiliki lima fase sebagai sintaks pembelajarannya. Adapun kelima fase tersebut adalah sebagai berikut:

Fase 1 : Berhadapan dengan masalah. Guru menjelaskan prosedur inquiry dan menyajikan peristiwa yang membingungkan.

Fase 2 : pengumpulan data untuk verifikasi. Menemukan sifat objek dan kondisi, menemukan terjadinya masalah.

Fase 3 : Pengumpulan data dalam eksperimen. Mengenali variabel-variabel yang relevan.

Fase 4 : Merumuskan penjelasan. Merumuskan aturan-aturan atau penjelasan-penjelasan.

Fase5 : menganalisis proses inquiry. Menganalisis strategi inquiry dan mengembangkannya. (Ngalimun,2014)

\section{METODE PENELITIAN}

Penelitian ini adalah penelitian quasi experiment dengan populasi seluruh siswa kelas X SMA Negeri 11 Medan yang berjumlah 8 kelas. Sampel penelitian ini terdiri dari 2 kelas yang ditentukan dengan teknik cluster random sampling, yaitu kelas X-8 sebagai kelas eksperimen dengan menggunakan model pembelajaran inquiry training dan kelas X-5 sebagai kelas kontrol dengan menggunakan pembelajaran konvensional.

Hasil belajar fisika siswa didapat dengan memberikan tes hasil belajar pada kedua kelas sampel sebelum dan sesudah diberi perlakuan. Selain itu, pada kelas eksperimen juga dilakukan observasi aktivitas siswa selama perlakuan diberikan. Desain penelitian yang digunakan desain penelitian two groups tes (pretes dan postes).

Data yang diperoleh ditabulasikan kemudian dicari rata- 
ratanya. Sebelum dilakukan analisis data, terlebih dahulu ditentukan nilai masing-masing kelompok sampel lalu dilakukan pengolahan data dengan langkah-langkah sebagai berikut yakni; menghitung nilai rata-rata dan simpangan baku, uji normalitas menggunakan uji Lilliefors, uji homogenitas menggunakan uji $\mathrm{F}$, pengujian kesamaan rata-rata pretes menggunakan uji $\mathrm{t}$ dua pihak dan pengujian hipotesis menggunakan uji $\mathrm{t}$ satu pihak pada data postes.

\section{HASIL PENELITIAN DAN PEMBAHASAN}

\section{Hasil Penelitian}

Penelitian diawalio terlebih dahulu dengan pemberian pretes yang bertujuan untuk melihat kemampuan awal siswa pada kelas eksperimen dan kelas kontrol. Hasil pretes siswa kelas eksperimen diperoleh rata-rata 22,80 dengan standar deviasi 8,62 sedangkan nilai pretes kelas kontrol adalah 26,00 dengan standar deviasi 9,13. Data di atas dapat dilihat pada Gambar 1 dan Gambar 2 berikut:

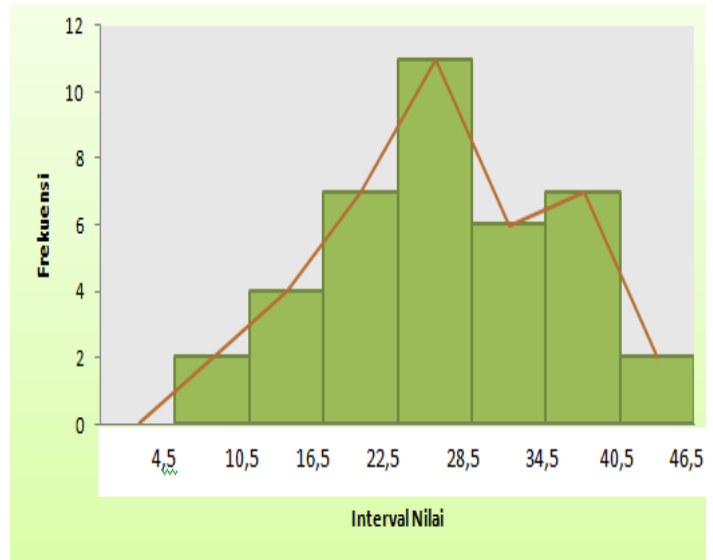

Gambar 1 Diagram Batang Data

Pretes Kelas Kontrol

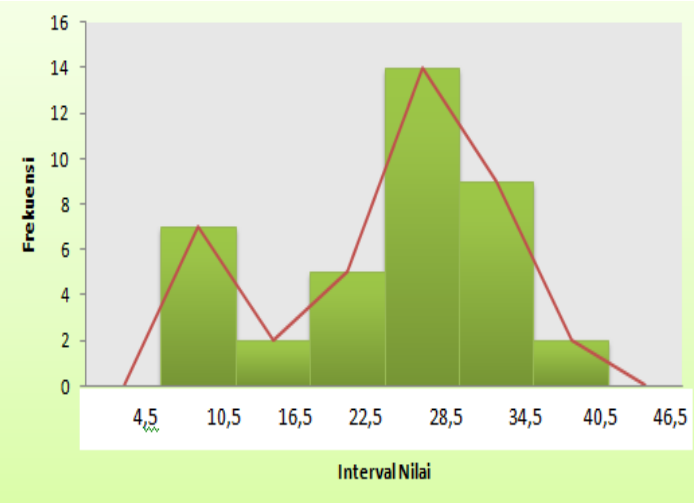

Gambar 2 Diagram Batang Data

Pretes Kelas Eksperimen

Setelah pada kelas eksperimen diberi perlakuan dengan model inquiry training dan pada kelas kontrol diberi pembelajaran konvensional, maka kedua kelas sampel diberi postes untuk melihat kemampuan akhir siswa. Data postes kedua kelas sampel dapat dilihat pada Gambar 3 dan Gambar 4 berikut:

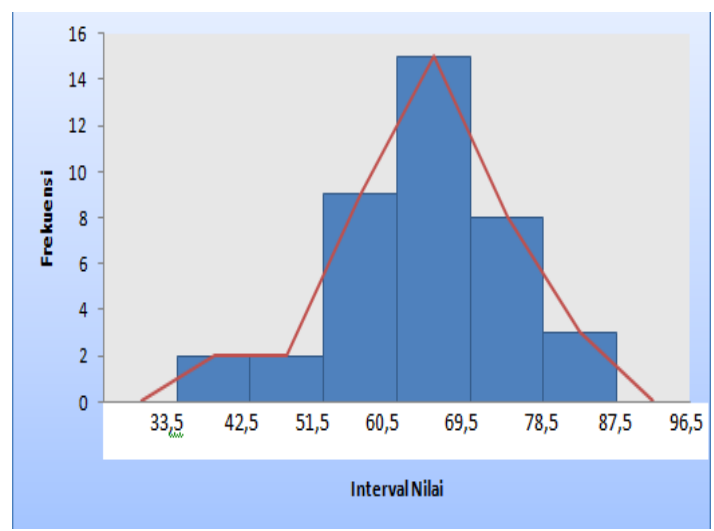

Gambar 3 Diagram Batang Data Postes Kelas Kontrol 


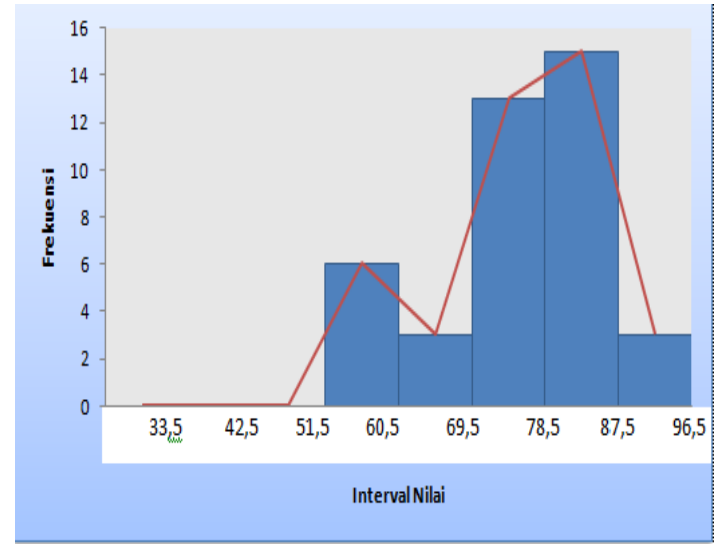

Gambar 4 Diagram Batang Data

Postes Kelas Eksperimen

Uji normalitas data pretes dan postes kelas eksperimen dan kelas kontrol digunakan untuk mengetahui apakah data pretes dan postes berdustribusi normal. Uji normalitas dilakukan dengan menggunakan uji lilliefors. Hasil uji lilliefors untuk kelas eksperimen diperoleh nilai pretes dengan harga $L_{\text {hitung }}=0,1141$ dan untuk nilai postes diperoleh harga $L_{\text {hitung }}=$ 0,0888 . Pada taraf signifikan $\alpha=0,05$ dan $\mathrm{n}=40$ diperoleh harga $L_{\text {tabel }}=$ 0,1401 maka $L_{\text {tabel }}>l_{\text {hitung. }}$ Hasil pengujian data di atas menunjukkan bahwa data tersebut berasal dari populasi yang berdistribusi normal. Hasil pengujian data untuk kelas kontrol diperoleh nilai pretes dengan harga $L_{\text {hitung }}=0,0814$ dan untuk nilai Postes dengan harga $L_{\text {hitung }}=0,0960$. Pada taraf signifikan $\alpha=0,05$ dan $\mathrm{n}=$ 39 diperoleh harga $L_{\text {tabel }}=0,1419$ maka $L_{\text {tabel }}>L_{\text {hitung. }}$ Hasil pengujian data di atas menunjukkan bahwa data tersebut berasal dari populasi yang berdistribusi nomal.

Uji homogenitas dilakukan untuk mengetahui apakah data pretes kelas eksperimen dan kelas kontrol homogen. Pengujian homogenitas data pretes kelas eksperimen dan kelas kontrol dilakukan dengan uji kesamaan dua varians, menunjukkan bahwa data dari kedua kelas tersebut adalah homogen yang berarti bahwa data yang diperoleh dapat mewakili seluruh populasi yang ada. Berdasarkan uji kesamaan dua varians untuk nilai pretes dan postes diperoleh harga $F_{\text {hitung }}$ sebesar 1,121 dan 1,130. Pada taraf signifikan $\alpha=0,05$ dan $\mathrm{n}$ untuk kelas kontrol $=39$ sedangkan $\mathrm{n}$ untuk kelas eksperimen $=40$ diperoleh harga $F_{\text {tabel }}$ $=1,746$ maka $F_{\text {hitung }}<F_{\text {tabel }}$. Hasil pengujian data di atas menunjukkan bahwa data yang diperoleh adalah homogen atau dapat mewakili seluruh populasi yang ada.

Hasil pemberian pretes kepada kelas eksperimen dan kelas kontrol diperoleh nilai rata-rata untuk kelas eksperimen adalah 22,80 dan nilai ratarata kelas kontrol adalah 26,00. Ringkasan perhitungan uji hipotesis untuk kemampuan pretes kelas eksperimen dan kelas kontrol diperoleh bahwa untuk nilai pretes $-t_{1-1 / 2^{\alpha}}<t<t_{1-1 / 2^{\alpha}}$ yaitu $-1,997<1,638$ < 1,997 maka $\mathrm{H}_{\mathrm{o}}$ diterima sehingga dapat disimpulkan bahwa kemampuan awal siswa pada kelas eksperimen sama dengan kemampuan awal siswa pada kelas kontrol. Pemberian perlakuan pada kelas eksperimen memberikan hasil bahwa nilai postes $t_{\text {hitung }}>\mathrm{t}_{\text {tabel }}$ yaitu 5,669 > 1,667 maka $\mathrm{H}_{0}$ ditolak dan $\mathrm{H}_{\mathrm{a}}$ diterima. Hal ini dapat dinyatakan bahwa hasil belajar kelas eksperimen lebih tinggi daripada kelas kontrol, berarti ada pengaruh model pembelajaran inquiry training pada materi listrik dinamis di kelas $\mathrm{X}$ semester genap SMA Negeri 11 Medan T.P 2015/2016.

Observasi dilakukan selama kegiatan belajar mengajar yang terdiri dari tiga kali pertemuan yang dilakukan oleh dua orang observer yaitu rekan sejawat. Selama penelitian ini, 
peningkatan yang terjadi setiap pertemuan pembelajaran dihitung dengan rumus $\mathrm{n}$-gain. Indikator yang diamati pada observasi ini adalah kegiatan visual, kegiatan lisan, kegiatan mendengarkan, kegiatan menggambar, kegiatan motorik, kegiatan mental dan kegiatan emosional. Setiap observer diberi lembar deskriptor untuk memudahkan penilaian selama penelitian berlangsung. Hasil observasi menunjukkan rata-rata nilai gain pada pertemuan I ke pertemuan II untuk semua kelompok adalah 0,58 dengan kategori sedang dan rata-rata nilai gain pada pertemuan II ke pertemuan III adalah 0,86 dengan kategori tinggi. Hasil observasi nilai gain untuk peningkatan aktivitas belajar siswa adalah 0,86 dengan interpretasi tinggi. Hasil observasi aktivitas siswa selama penelitian di atas menyimpulkan bahwa dengan menerapkan model pembelajaran inquiry training dapat meningkatkan keaktifan siswa dalam belajar.

Peningkatan n-gain dari pertemuan I sampai Pertemuan III dapat dilihat pada Gambar 6 berikut :

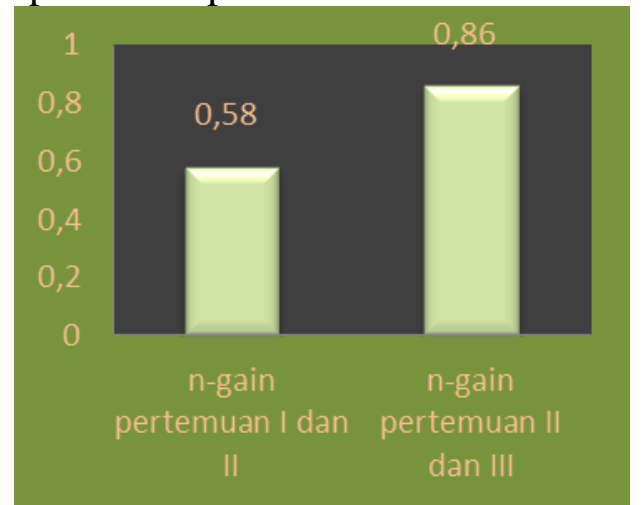

Gambar 6 Diagram batang n-gain aktivitas siswa

Pengaruh model pembelajaran
inquiry training memberikan
perbedaan terhadap hasil belajar pada
aspek pengetahuan dikarenakan model pembelajaran inquiry training mempunyai lima tahap atau fase pembelajaran yang membuat pengetahuan siswa menjadi lebih baik dan meningkat. Selama penelitian berlangsung pada pertemuan pertama hingga pertemuan ketiga diperoleh bahwa pada fase 1 yaitu menghadapkan pada masalah, pada pertemuan pertama siswa masih terlihat bingung dan kurang aktif untuk memberikan respon pembelajaran yang diberikan peneliti, masih banyak yang diam, tetapi pada pertemuan kedua siswa sudah mulai memberikan tanggapan atau respon dengan satu dan dua orang yang memberikan argumen ataupun pertanyaan hingga pada pertemuan ketiga sudah banyak siswa yang berargumen atau memberikan pertanyaan dengan stimulus pembelajaran yang diberikan peneliti kepada siswa.

Fase 2, 3 dan 4 yaitu tahapan mengumpulkan data verifikasi, mengumpulkan data eksperimentasi, dan mengolah, memformulasikan suatu penjelasan dimana pada tahap ini siswa melakukan eksperimen, pada pertemuan pertama terjadi keributan sesama siswa karena pembagian kelompok yang tidak biasa dilakukan pada pembelajaran sehingga peneliti sulit untuk mengatur, kemudian siswa bingung dan berkomentar dengan masalah yang diberikan oleh peneliti, karena mereka jarang mendapatkan masalah fisika dalam pembelajaran sebelumnya sehingga peneliti menjelaskan berulang kembali mengenai masalah yang disajikan hingga mereka paham apa yang dimaksud pada masalah tersebut, tetapi setelah dilihat dari pertemuan kedua pembagian kelompok semakin kondusif hingga siswa semakin paham 
mengenai masalah yang disajikan dan pada pertemuan ketiga kegiatan eksperimen berjalan dengan baik dan siswa tidak lagi bingung dan berkomentar mengenai masalah dan dapat mengolah data yang didapat.

Fase 5 yaitu analisis proses penelitian, pada pertemuan pertama siswa belum bisa untuk menganalisis penemuan konsep yang didapat pada praktikum dengan konsep yang ada dibuku referensi sehingga pada waktu membuat kesimpulan tidak sesuai dengan masalah yang diberikan, sehingga peneliti kembali menjelaskan kepada siswa agar kesimpulan yang didapat harus sesuai dengan masalah yang diberikan peneliti dan mampu menghubungkan konsep yang ditemukan pada eksperimen dengan konsep yang ada pada buku ataupun referensi lainnya, kemudian pada pertemuan kedua hingga ketiga siswa sudah semakin paham dan kesimpulan yang didapat sesuai dengan yang diharapkan.

\section{SIMPULAN DAN SARAN \\ Simpulan}

Hasil observasi aktivitas belajar siswa setelah menerapkan model pembelajaran inquiry training diperoleh nilai gain pertemuan I ke pertemuan II terjadi rata-rata peningkatan n-gain sebesar 0,58 dengan kategori sedang dan dari pertemuan II ke pertemuan III diperoleh rata-rata peningkatan n-gain sebesar 0,86 dengan kategori tinggi.

Ada pengaruh yang signifikan dari model pembelajaran inquiry training terhadap hasil belajar siswa pada materi pokok listrik dinamis di kelas X SMA Negeri 11 Medan T.P 2015/2016.

\section{Saran}

Saran bagi peneliti selanjutnya yang ingin melakukan penelitian dengan menggunakan model pembelajaran inquiry training, sebaiknya lebih menguasai lagi terlebih dahulu setiap sintaks yang terdapat dalam model, supaya kegiatan pembelajaran dapat berlangsung dengan baik. Peneliti selanjutnya juga hendaknya harus lebih tegas lagi dalam mengontrol kelas saat melaksanakan diskusi kelompok sehingga kelas menjadi lebih kondusif.

\section{Daftar Pustaka}

Joyce, B., Weil, M.. 2009. ModelModel Pembelajaran, Edisi Delapan, Pustaka Belajar, Yogyakarta

Ngalimun. (2014). Strategi dan Model Pembelajaran, Aswajah Pressindo: Yogyakarta

Rusman, (2010), Model-model Pembelajaran,

Mengembangkan

Profesionalisme Guru, Raja Grafindo Persada, Jakarta.

Sanjaya, W. 2005. Pembelajaran Dalam Implementasi Kurikulum Berbasis Kompetensi. Prenada Media: Jakarta.

Sanjaya, W. (2010). Strategi Pembelajaran Berorientasai Standar proses Pembelajaran Pendidikan, Kencana: Jakarta

Sardiman. (2009). Interaksi dan Motivasi Belajar Mengajar, Penerbit, PT Raja Grafindo Persada

Toenas S. 2012. Penerapan Model Inquiry Training Melalui Teknik Peta Konsep dan Teknik Puzzle Ditinjau Dari Tingkat Keberagaman Aktivitas Belajar Dan Kemampuan Memori, 
Jurnal Inkuiri Volume 1 Nomor 32012

Trianto. 2011. Mendesain Model Pembelajaran Inovatif Progresif, Kencana Prenada Media Group, Jakarta 